\title{
Relative production of Calanoides acutus (Copepoda: Calanoida) and Euphausia superba (Antarctic krill) at South Georgia, and its implications at wider scales
}

\author{
Rachael S. Shreeve*, Geraint A. Tarling, Angus Atkinson, Peter Ward, Cathy Goss, \\ Jonathon Watkins
}

British Antarctic Survey, Natural Environment Research Council, High Cross, Madingley Road, Cambridge CB3 0ET, UK

\begin{abstract}
Antarctic krill are often described as the major species in Southern Ocean food webs, but there have been no direct site-specific comparisons between their production and that of copepods that dominate mesozooplankton biomass. Here, we compare biomass, growth and production of Euphausia superba (Antarctic krill) and the copepod Calanoides acutus at South Georgia, in the Atlantic sector of the Southern Ocean. Average acoustically derived krill biomass across the 5 study years was $2.6 \mathrm{~g} \mathrm{C} \mathrm{m}^{-2}$, 4 to 5 times that of Stages CIV and CV of C. acutus. Mean length of krill was $41 \pm 4 \mathrm{~mm}$, and the average growth rate was $0.10 \mathrm{~mm} \mathrm{~d}^{-1}$, giving an average mass-specific growth rate of $0.0084 \mathrm{~d}^{-1}$. This equated to a daily gross production of krill of $0.022 \mathrm{~g} \mathrm{C} \mathrm{m}^{-2} \mathrm{~d}^{-1}$. Gross production of Stages CIV and CV of C. acutus was similar, around $0.026 \mathrm{~g} \mathrm{C} \mathrm{m}^{-2} \mathrm{~d}^{-1}$. These stages of C. acutus represent about $25 \%$ of the total copepod biomass around South Georgia, so total copepod production here may exceed that of krill by a factor of 4 during the productive summer months. Biomass of copepods and krill in other parts of the Southern Ocean differ by similar orders of magnitude, whilst growth rates are likely to remain within the range measured in this study. Therefore, our finding has relevance outside the local South Georgia system. All of the krill production is likely to be rapidly consumed by higher predators within the surface layers, whilst it is estimated that around $17 \%$ of copepod production may be sequestered at depth during winter diapause.
\end{abstract}

KEY WORDS: Copepods · Calanoides acutus · Antarctic kill · Secondary production · South Georgia · Southern Ocean

Resale or republication not permitted without written consent of the publisher

\section{INTRODUCTION}

Antarctic krill Euphausia superba and copepods are key taxa in the Southern Ocean, forming important links between primary production and higher trophic levels. Of the two, krill have received more attention (e.g. Everson 1977, Tranter 1982, Clarke 1985, Hempel 1985, Miller \& Hampton 1989, Quetin \& Ross 1991), largely because of their dietary importance for many vertebrate predators and commercially important species of fin-fish. However, the renewed focus on carbon flux and energy transfer through marine ecosystems shows that Southern Ocean copepods also play an important role.

Few studies have actually attempted to quantify the production of either group in the Southern Ocean. Conover \& Huntley (1991) made indirect estimates for copepods, concluding that, on a circumpolar scale, copepod production could be triple that of krill. Voronina (1998) suggested that annual copepod production may exceed that of krill by a factor of 12 . However, both of these studies stressed that the estimates were preliminary and very approximate, the former being based on rates of ingestion and assimilation, and the 
latter, on published $P / B$ coefficients. There have been no comparisons based on direct measurements of production of copepods and krill on a site-specific basis.

The aim of the present study was to improve understanding of energy flow through the Southern Ocean food web by measuring the biomass and production of krill and the calanoid copepod Calanoides acutus, based on direct measurements on a site-specific basis. The study was undertaken around South Georgia, an area renowned for supporting a high standing stock of both krill and copepods (Ward et al. 1995, Atkinson et al. 2001). Biomass was measured over 5 summer seasons. C. acutus growth was derived from data collected during 4 of the years, whilst krill growth was measured during the fifth year. During the final year a spatial comparison was made to address the patchiness in production of these 2 groups.

\section{MATERIALS AND METHODS}

Surveys. In this paper we utilize data from 5 RRS 'James Clark Ross' monitoring surveys between 1996 and 2002, NW of South Georgia (Fig. 1). All of these were carried out during the summer period from midDecember to the end of February. Biomass of copepods was measured with nets, while that of krill was measured acoustically. Differences in the biomass of copepods at scales of kilometres are unlikely to be large (usually within 1 order of magnitude; Mauchline 1998). Therefore, making estimates from point samples, using vertically towed nets, is a reasonable way to determine the biomass of the wider region, at the scale of 1 to $10 \mathrm{~km}$ (Harris et al. 2000). Determining the biomass of Antarctic krill with nets is less suitable, because they are distributed in a much more patchy manner as a result of their tendency to form discrete swarms and aggregations across a range of scales (Murphy et al. 1988, Hamner \& Hamner 2000) and have noticeable net avoidance capabilities (Watkins 2000). Estimating krill biomass using acoustic echo-integration techniques along transects overcomes some of these problems, since the echosounder produces a continuous quantitative record of krill distribution over transects spanning $10 \mathrm{~s}$ to $100 \mathrm{~s}$ of kilometres (MacLennan \& Simmonds 1992). Sampling depths were different between the 2 groups, but previous studies (Atkinson et al. 1997, Godlewska 1996) showed that the bulk of the populations lay within the chosen depth ranges of each sampling device. These methods are currently the best to assess biomass for each species.

During all years, 8 stations were routinely sampled within a monitoring grid called the 'western core box' (WCB; Fig. 1). These samples were used to measure mesozooplankton abundance and species composition as well as biomass and growth rates of selected species and stages of copepods. Additionally, during the fifth year, krill growth measurements were made alongside

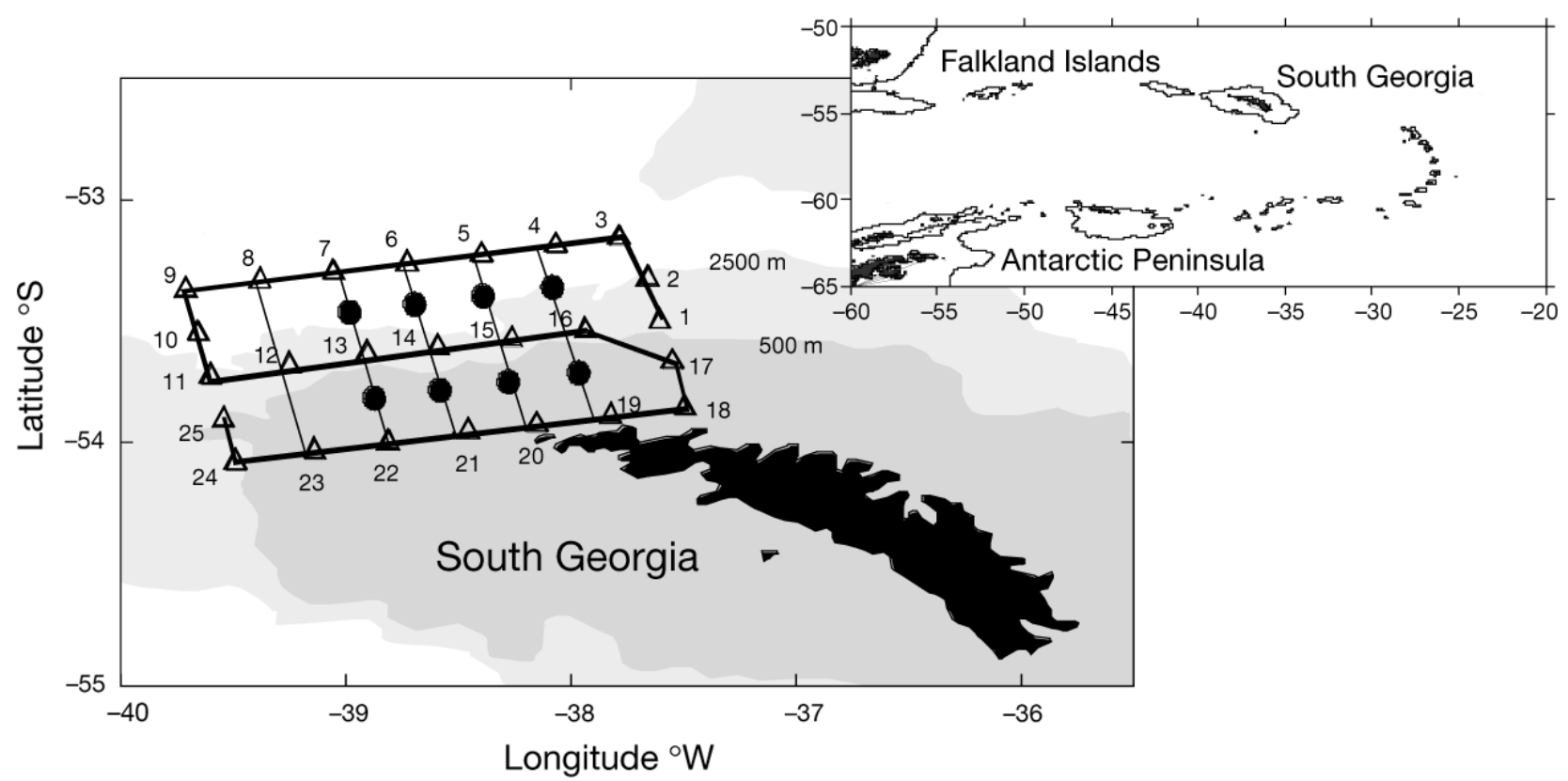

Fig. 1. Study area showing routine station locations demarking the western core box (WCB, $\bullet$ ) survey, used during all 5 years of the study period, and the more dense sample stations of the boundary box $(B B, \Delta)$ survey, used during the final year; the latter stations are numbered from 0 to 25 for cross reference to Table 5. Transects surveyed are represented by a thin line (each line represents a transect pair) for the WCB or a thick line for the BB 
the standard copepod measurements for 25 stations within the boundary box (BB; Fig. 1).

Krill biomass. Krill biomass (wet mass, WM, $\mathrm{g} \mathrm{m}^{-2}$ ) was determined acoustically between 7 and $250 \mathrm{~m}$. The acoustic data were collected with an echosounder operating at 38 and $120 \mathrm{kHz}$. Acoustic signals arising from Antarctic krill were separated from other sources of acoustic backscatter $\left(S_{\mathrm{v}}\right)$ using a dual-frequency discrimination technique (Maduriera et al. 1993, Brierley et al. 1997, Watkins \& Brierley 2002). A difference in mean volume backscattering strength $\mathrm{D} S_{\mathrm{v}}$ at 38 and $120 \mathrm{kHz}$ (where $\mathrm{D} S_{\mathrm{v}}=S_{\mathrm{v} 120}-S_{\mathrm{v} 38}$ ) of between 2 and $12 \mathrm{~dB}$ was used to discriminate Antarctic krill from other species (Watkins \& Brierley 2002). Vertically and horizontally integrated $S_{\mathrm{v}}$ was converted into krill WM $\left(\mathrm{g} \mathrm{m}^{-2}\right)$ using the targetstrength to mass relationship of Brierley \& Watkins (1996; -39 dB kg-1 krill WM).

Three acoustic survey designs were carried out. The first, which covered the WCB (Fig. 1), was carried out during the first $4 \mathrm{yr}, 1996$ to 2000, and comprised a series of $10 \mathrm{NW}-\mathrm{SE}$-orientated parallel transects, each $80 \mathrm{~km}$ in length and around $10 \mathrm{~km}$ apart (see Brierley et al. 1997 for full details). Surveying was during daylight only. The second survey design, carried out in the final year, 2001/2002, involved a small increase in the size of the survey box and a decrease in the number of transects from 10 to 8 . The third survey design, also carried out in the final year, covered the BB (Fig. 1), with acoustic surveys taking place both day and night and consisting of a combination of short transects between stations (approximately $18 \mathrm{~km}$ apart). All transects during all years were steamed at a nominal speed of 10 knots.

For the $\mathrm{BB}$, values $9 \mathrm{~km}$ each side of a station (approximately half way between one station and the next) were combined to give an average krill WM $\left(\mathrm{g} \mathrm{m}^{-2}\right)$ for each of the 25 stations labeled in Fig. 1. Krill WM $\left(\mathrm{g} \mathrm{m}^{-2}\right)$ was converted to carbon mass $\left(\mathrm{CM}, \mathrm{g} \mathrm{m}^{-2}\right)$ by assuming dry mass (DM) as $25 \%$ of WM (from Morris et al. 1988) and CM as $40 \%$ of DM (Schnack 1985, Ikeda \& Kirkwood 1989). For the WCB, krill biomass was determined for each transect. Values for every $0.5 \mathrm{~km}$ integration interval along transects were averaged to give a mean biomass for each transect from which a weighted mean biomass for the WCB was calculated (Jolly \& Hampton 1990). Note that BB and WCB acoustic data are not directly comparable because of the night-time sections included in the BB data.

Krill instantaneous growth rate experiments. During 2002, rectangular midwater trawl (RMT8) hauls for live krill were targeted at acoustically detected swarms. The RMT8 comprised 2 nets with non-filtering cod ends, thus allowing 2 separate swarms to be sam- pled during 1 haul. Hauls lasted no longer than 20 min, to ensure that krill were in good condition. After recovery of the net, most krill were immediately transferred to ambient surface seawater in $150 \mathrm{l}$ circular containers kept in a constant-temperature room and maintained at ambient seawater temperature (approximately $2^{\circ} \mathrm{C}$ ); 100 individuals were immediately frozen at $-80^{\circ} \mathrm{C}$ (hereafter called $T_{0}$ samples) for length-mass regression analysis in the UK.

Krill growth rates were determined using the instantaneous growth rate (IGR) method (Quetin \& Ross 1991, Nicol et al. 1992, Ross et al. 2000). Freshly caught krill were incubated individually in $500 \mathrm{ml}$ perforated pots, situated in tanks of $\sim 0.5 \mathrm{~m}^{3}$. These tanks were maintained at ambient seawater temperature, while a constant supply of seawater was added at a rate that exchanged the entire tank contents approximately 3 times daily. This through-flow was from the ship's nontoxic supply, first pumped through a heavy-duty filtration unit that removed all particles $>2 \mu \mathrm{m}$.

Krill were maintained for $5 \mathrm{~d}$, and were checked daily for individuals that had molted. Their intermolt period (IMP, in days) was determined as:

$$
\operatorname{IMP}=1 /\left(\left[\frac{m}{T}\right] / d\right)
$$

where $T$ is the total number of krill incubated in all experiments and $m$ is the total number of krill that molted during the experimental duration $d$ (in days). Over 2000 individuals were incubated from 17 swarms (Table 1). This overall estimate is more robust than those from specific swarms that are prone to molt synchrony (G. A. Tarling et al. unpubl. data).

For those krill that had molted, left and right uropods were measured on both the newly molted animal and its recently molted exoskeleton. This was done on board ship after each molt check, under a binocular microscope with an eye-piece graticule at a magnification of $\times 12$ (to a precision of $\pm 0.04 \mathrm{~mm}$ ). We defined the growth increment (GI) per IMP as the percentage growth or shrinkage of the initial length achieved during the previous intermolt period, such that:

$$
\mathrm{GI}=\left(\frac{f-1}{i}\right) \times 100
$$

where $f$ and $i$ are the lengths of the uropods of the freshly molted individual and its old exoskeleton, respectively. A mean of both left and right was used, with damaged uropods excluded from the analysis. The average daily percentage increment in length is thus the GI divided by the IMP.

Either on molt or at the end of the experiment, molters and non-molters were measured and their sex and maturity stage were categorized according to Morris 
Table 1. Euphausia superba. Summary of instantaneous growth rate experiments. 'Event' is the unique number given to a krill swarm sampled, the numeral behind the decimal place indicates which cod end the sample was caught in (location of the swarms is shown in Fig. 3). Data are shown for mean length of krill in each swarm (mm), the number incubated and the number molting during the $5 \mathrm{~d}$ incubations used to calculate intermolt period (IMP). The growth increment (GI, percentage per IMP) was averaged over the first $2 \mathrm{~d}$ of incubation (-: no animals molting on the first $2 \mathrm{~d}_{i}{ }^{* *}$ : only incubated for $2 \mathrm{~d}$, therefore no IMP calculated)

\begin{tabular}{|cccccc|}
\hline Event & $\begin{array}{c}\text { Mean } \\
\text { length } \\
\text { (mm) }\end{array}$ & $\begin{array}{c}\text { Number } \\
\text { incu- } \\
\text { bated }\end{array}$ & $\begin{array}{c}\text { Number } \\
\text { molted }\end{array}$ & IMP & GI \\
\hline 89.1 & 41 & 318 & 103 & 15 & 7.99 \\
89.2 & 41 & 77 & 17 & 23 & 10.59 \\
134.2 & 53 & 56 & 6 & 47 & 4.80 \\
164.1 & 39 & 120 & 25 & 24 & 3.51 \\
165.1 & 40 & 163 & 37 & 18 & - \\
165.2 & 40 & 151 & 24 & 25 & - \\
254.1 & 42 & 54 & 14 & 23 & - \\
254.2 & 44 & 54 & 19 & 17 & 5.65 \\
276.2 & 42 & 232 & 107 & 15 & 4.51 \\
286.1 & 46 & 69 & 28 & 15 & 2.11 \\
291.1 & 43 & 39 & 19 & 14 & 3.15 \\
291.2 & 42 & 47 & 13 & 25 & 3.89 \\
301.1 & 54 & 87 & 18 & 24 & 1.98 \\
302.1 & 41 & 258 & 27 & 48 & 2.28 \\
302.2 & 41 & 16 & 4 & 20 & 3.28 \\
357.1 & 41 & 181 & 3 & ${ }^{* *}$ & 3.57 \\
357.2 & 41 & 107 & 7 & $* *$ & 3.81 \\
\hline
\end{tabular}

et al. (1988). Total length was measured from the front of the eye to the tip of the telson. For consistency R. S. Shreeve made all measurements.

Although experiments were run for $5 \mathrm{~d}$, growth significantly decreased with the length of time krill were held in incubations (G. A. Tarling et al. unpubl. data). Therefore, the growth-rate data presented in this paper are an average of the first $2 \mathrm{~d}$ only. Maintaining krill for this duration is considered to provide a good approximation of in situ growth rates (Nicol et al. 1992, Quetin et al. 1994). The mortality rate over the first $2 \mathrm{~d}$ was $0.8 \% \mathrm{~d}^{-1}$.

Krill length-mass regressions. Length-mass regressions were constructed in the UK from $30 T_{0}$ individuals from each swarm. Length, sex and maturity state were recorded before freeze-drying for $24 \mathrm{~h}$ under a vacuum and weighing, to a precision of $\pm 10 \mu \mathrm{g}$, on a Mettler AT 250 balance. Coefficients for each sex and maturity stage were derived as:

$$
\log _{10} M=\beta+\left(\alpha \times \log _{10} L\right)
$$

where $M$ is body DM (mg), $\beta$ and $\alpha$ are constants and $L$ is length $(\mathrm{mm})$.

Mean length of krill measured fresh compared to those frozen at $-80^{\circ} \mathrm{C}$ before analysis showed no sig- nificant difference, so it is assumed that freezing had no effect on the length-mass regressions.

Mass-specific growth rates of krill. Mass-specific growth rates $(g)$ of molting krill were determined by first estimating the pre-molt length $\left(L_{0}\right)$ such that:

$$
L_{0}=\frac{100-\mathrm{GI}}{100} \times L_{1}
$$

where $L_{1}$ is the length after molt. Applying the maturity stage-specific length-mass regression, masses of the individuals before and after molting were determined. Thus, $g\left(\mathrm{~d}^{-1}\right)$ was determined as:

$$
g=\left(\ln M_{i+1}-\ln M_{i}\right) / \mathrm{IMP}
$$

where $M_{i}$ is the estimated mass of the krill at the time of the previous molt (i.e. before capture) and $M_{i+1}$ is the estimated mass of the freshly molted krill (mg C).

Copepod biomass. Plankton samples were collected at each station on the WCB and BB (Fig. 1) with a motion-compensating Bongo net. Each net had a mouth diameter of $61 \mathrm{~cm}$, a mesh size of $200 \mu \mathrm{m}$ and a solid cod end. Nets were hauled from $200 \mathrm{~m}$ to the surface, where water depth allowed, and the sample was diluted with ambient seawater. In the ship's laboratory 1 catch was sorted and the other was preserved in $4 \%$ formaldehyde in seawater, for species identification and enumeration in the UK.

To investigate copepod production we required ubiquitous species and stages that dominated copepod biomass at this time of year. Calanoides acutus was thus selected, with Stages CIV and CV being dominant. These were sorted for DM, CM and NM determinations. Copepods were rinsed in $4 \%$ ammonium formate, dabbed dry, placed in pre-weighed tinfoil capsules and dried onboard ship at $60^{\circ} \mathrm{C}$ for $24 \mathrm{~h}$. Samples were then stored in a desiccator and weighed on a Mettler MT5 balance in the UK. CM and NM were measured using a Carlo Erba 1108 elemental analyzer, using acetanilide as the standard.

Copepod mass-specific growth rate. Standard methods of estimating growth rates of copepods rely on individuals molting and developing through the various copepodite stages. This method cannot be applied to Calanoides acutus Stages CIV and CV, because at least some of the individuals have reached their terminal molt for that season. We therefore adapted a modeling approach to estimate the mass-specific growth rates of these stages. Tarling et al. (2004) developed a life-cycle model for $C$. acutus that was parameterized with CM measurements of the developmental stages of C. acutus, obtained from samples taken during the same surveys. Full details on the construction of this model are presented in their paper so only a summary of the functions relevant to the present study will be 
Table 2. Calanoides acutus. Mean abundance, carbon mass (CM) and biomass (BM) for Stages CIV and CV for each of the 5 years studied, standard deviation in parentheses

\begin{tabular}{|c|c|c|c|c|c|c|}
\hline \multirow[t]{2}{*}{ Year } & \multicolumn{2}{|c|}{$\begin{array}{c}\text { Abundance } \\
\text { (ind. } \mathrm{m}^{-2}, 0-200 \mathrm{~m} \text { ) }\end{array}$} & \multicolumn{2}{|c|}{$\begin{array}{c}\mathrm{CM} \\
\left(\mu \mathrm{g} \mathrm{C} \text { ind. }{ }^{-1}\right)\end{array}$} & \multicolumn{2}{|c|}{$\begin{array}{c}\mathrm{BM} \\
\left(\mathrm{g} \mathrm{C} \mathrm{m}^{-2}, 0-200 \mathrm{~m}\right)\end{array}$} \\
\hline & CIV & $\mathrm{CV}$ & CIV & $\mathrm{CV}$ & CIV & $\mathrm{CV}$ \\
\hline 1995/1996 & 363 (451) & 349 (264) & 34 (10) & 256 (118) & $0.01(0.01)$ & $0.09(0.07)$ \\
\hline 1996/1997 & 2261 (2015) & 2949 (2256) & $28(6)$ & $172(49)$ & $0.06(0.06)$ & $0.51(0.39)$ \\
\hline 1997/1998 & 1968 (1306) & 6611 (2993) & 35 (11) & 248 (117) & $0.07(0.05)$ & $1.52(0.74)$ \\
\hline 1998/1999 & 747 (427) & $1474(1054)$ & $47(9)$ & 191 (128) & $0.04(0.02)$ & $0.28(0.20)$ \\
\hline $2001 / 2002$ & 503 (606) & 1666 (1598) & $52(42)$ & $258(174)$ & $0.03(0.03)$ & $0.43(0.43)$ \\
\hline
\end{tabular}

given below. First, it was necessary to determine the age/mass coordinates for $C$. acutus copepodite stages by assuming that some stages overwinter. A 2-parameter growth equation of the following form was fitted to these coordinates as follows:

$$
\mathrm{C}_{\text {mass }}=0.6026 \times \text { age }^{1.429} \quad \mathrm{r}^{2}=0.99
$$

where $\mathrm{C}_{\text {mass }}$ is the carbon mass in $\mu \mathrm{g}$ and age is in days after the mid-stage of $\mathrm{CI}$ is reached.

To determine the IGR for Stages CIV and CV, this growth curve was first differentiated to give:

$$
\frac{\delta \mathrm{C}_{\text {mass }}}{\text { Sage }}=0.86 \times \text { age }^{0.429}
$$

The equation was then solved for the average ages of CIV and CV (23 and 48 d beyond the mid-stage of CI, respectively).

To give a mass-specific instantaneous rate of growth $(g)$ comparable to that of krill, the above values were divided by the average respective carbon masses of Stages CIV and CV (39 and $195 \mu \mathrm{g}$, respectively). This resulted in a value of $g$ of 0.11 for Stage CIV and a value of 0.04 for Stage CV. The value of $g$ derived through direct measurements $(0.14$, Shreeve et al. 2002) of CIV individuals was somewhat higher than that calculated above. The values of $g$ derived from the model can therefore be considered to be on the conservative side.

Production ( $\left.P, \mathrm{~g} \mathrm{C} \mathrm{m} \mathrm{m}^{-2} \mathrm{~d}^{-1}\right)$ was calculated by multiplying estimated biomass $\left(B, \mathrm{~g} \mathrm{C} \mathrm{m}^{-2}\right)$ by the mass-specific growth rate $\left(g, \mathrm{~d}^{-1}\right)$ :

$$
P=B \times g
$$

During all years, temperature and chlorophyll a were recorded at each station. Water temperature $\left({ }^{\circ} \mathrm{C}\right)$ was integrated over the top $60 \mathrm{~m}$ from CTD casts taken at each station. Surface chlorophyll a concentration $\left(\mathrm{mg} \mathrm{m}^{-3}\right)$ was measured according to Korb et al. (2004).

\section{RESULTS}

\section{Biomass}

Calanoides acutus was abundant over much of the survey area during most years, although a wide range of abundance, carbon and dry-mass values was observed. During 1995/1996 Stages CIV and CV were scarce (Table 2), suggesting poor recruitment that year. However, the survey was carried out later in the year (February), and an overwintering descent of the copepodite stages cannot be discounted. Mean abundance of Stages CIV and CV over all years was 1168 and 2609 individuals (ind.) $\mathrm{m}^{-2}$, respectively. Higher abundances were generally found in water with deeper bathymetry in all years. Carbon masses of Stages CIV and CV were variable (Table 2), but averaged 39 and $225 \mu \mathrm{g} \mathrm{C}$ ind. ${ }^{-1}$, respectively. Abundance and carbon mass were not significantly related, although an increase in biomass was generally associated with an increase in abundance and a decrease in carbon mass per individual.

Krill Euphausia superba biomass $\left(\mathrm{g} \mathrm{C} \mathrm{m} \mathrm{m}^{-2}\right.$ ) was higher than that of Calanoides acutus (Stages CIV and $\mathrm{CV}$ ) in all years studied. Biomass ranged from 1.20 to $4.66 \mathrm{~g} \mathrm{C} \mathrm{m}^{-2}$ and from 0.1 to $1.59 \mathrm{~g} \mathrm{C} \mathrm{m}^{-2}$ for krill and C. acutus, respectively (Table 3 ). Relative biomass between the 2 groups was highly variable, ranging

Table 3. Biomass of Antarctic krill Euphausia superba and Calanoides acutus Stages CIV and CV; coefficients of variation (\%) are in parentheses. Mean temperature $(0-60 \mathrm{~m})$ and surface chlorophyll a $(\mathrm{chl} \mathrm{a})$ for the western core box during each year are also provided

\begin{tabular}{|lcccc|}
\hline Year & \multicolumn{2}{c}{ Biomass $\left(\mathrm{g} \mathrm{C} \mathrm{m}^{-2}\right)$} & Mean temp. & $\begin{array}{c}\text { Chl } a \\
\left(\mathrm{mg} \mathrm{m}^{-3}\right)\end{array}$ \\
& E. superba & C. acutus & & \\
\hline $1995 / 1996$ & $2.67(28.76)$ & $0.10(44.72)$ & $2.55 \pm 0.63$ & $2.36 \pm 0.77$ \\
$1996 / 1997$ & $2.52(17.06)$ & $0.57(40.83)$ & $2.93 \pm 0.68$ & $4.00 \pm 0.59$ \\
$1997 / 1998$ & $2.14(19.80)$ & $1.59(35.36)$ & $1.98 \pm 0.21$ & $5.85 \pm 2.52$ \\
$1998 / 1999$ & $1.20(12.16)$ & $0.32(35.36)$ & $2.63 \pm 0.17$ & $4.79 \pm 0.81$ \\
$2001 / 2002$ & $4.66(40.22)$ & $0.46(31.62)$ & $3.11 \pm 0.66$ & $4.85 \pm 0.21$ \\
\hline
\end{tabular}


from a ratio of 1.3 to 26.7 . No positive or negative correlations were apparent in the relative abundances of the 2 species, either temporally or spatially. However, krill were generally more abundant over the shelf, close to the land mass, as illustrated in Fig. 2A, whilst copepod biomass was higher off the shelf, in deeper waters (Fig. 2B).

\section{Instantaneous growth rate of krill}

During 2002 most of the large aggregations of krill that were encountered were sampled to measure GI. Overall, krill sampled from all swarms were of a similar length (mean $41 \pm$ $4 \mathrm{~mm}$ ). Approximately half of the individuals sampled were sub-adult females, with subadult males making up most of the remainder. The GI of individual swarms varied from 1.98 to $10.59 \%$ body length per IMP (Table 1, Fig. 3), with a mean of $4.37 \%$. This equates to approximately $1.79 \mathrm{~mm}$ per IMP, or a daily increment of $0.10 \mathrm{~mm} \mathrm{~d}^{-1}$ with an $18 \mathrm{~d}$ IMP. Negative growth was observed in $2 \%$ of molting individuals, whilst $10 \%$ showed zero growth and the remainder was positive. Accordingly the mean daily mass-specific growth rate $(g)$ for krill was $0.0084 \pm 0.0069$ (range: -0.022 to 0.040 ) .

Mean temperature in the top $60 \mathrm{~m}$ ranged from 1.98 to $3.11^{\circ} \mathrm{C}$, and surface chlorophyll $a$ ranged from 2.36 to $5.85 \mathrm{~g} \mathrm{~m}^{-3}$, but neither was significantly different between years (Table 3 ). We can assume that krill IGR experiments were carried out in conditions that were typical for the South Georgia region.

\section{Krill and copepod production}

Over the years studied, dominance in production fluctuated between the 2 groups. That of Calanoides acutus Stages CVI and CV was higher than that of krill in 3 out of the 5 summer seasons (Table 4). Its production, averaged over all 5 years (Stages CIV and CV combined), was $0.026 \mathrm{~g} \mathrm{C} \mathrm{m}^{-2} \mathrm{~d}^{-1}$, slightly higher than that of krill (0.022 $\left.\mathrm{g} \mathrm{C} \mathrm{m}^{-2} \mathrm{~d}^{-1}\right)$.

Spatial comparisons carried out in the final year revealed that high krill production was centered in a small area over the shelf, very close to the island, whilst remaining relatively low over the rest of the survey box (Table 5, Fig. 2C). Calanoides acutus production was higher over a greater area than that of krill.
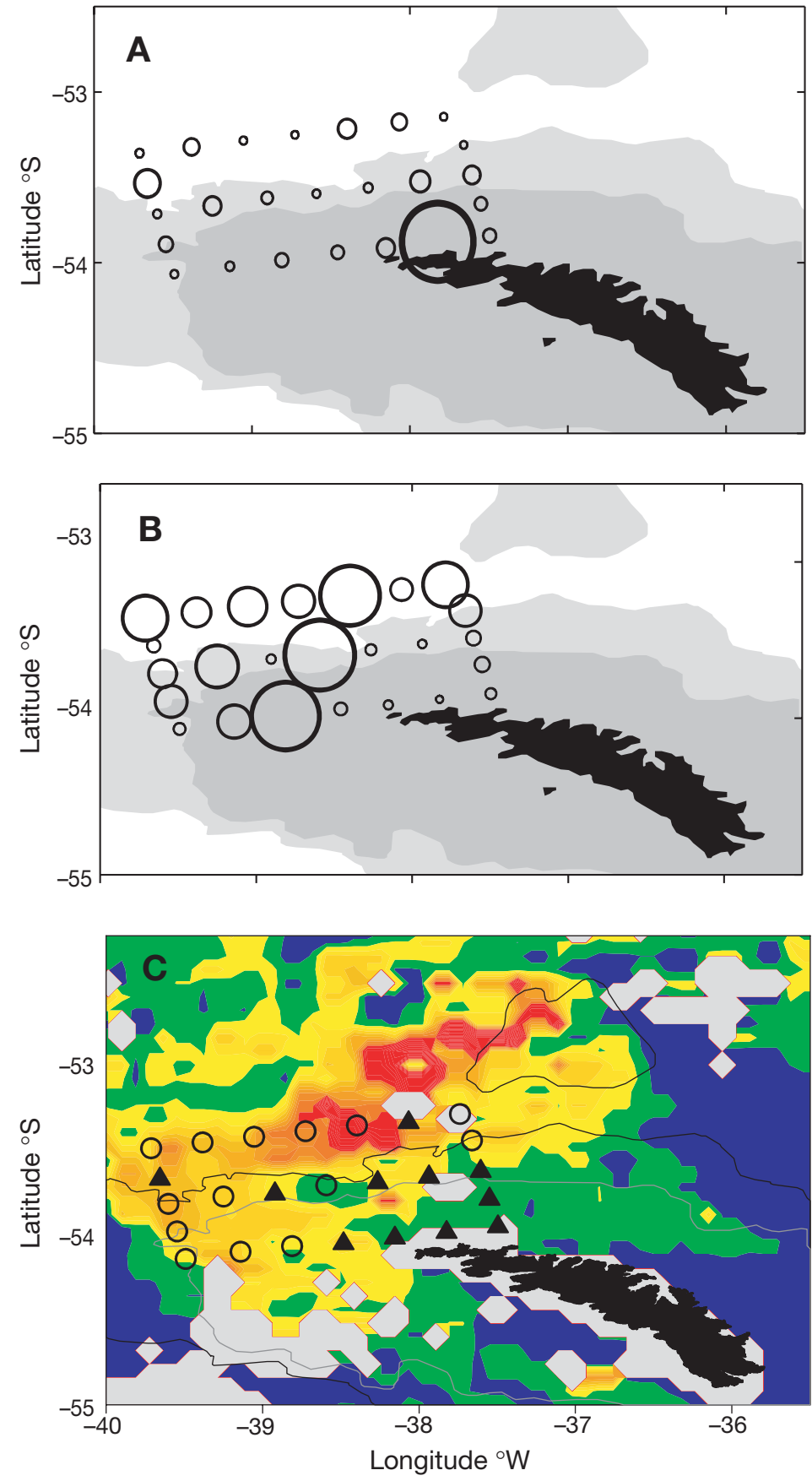

Chlorophyll a $\left(\mathrm{mg} \mathrm{m}^{-3}\right)$

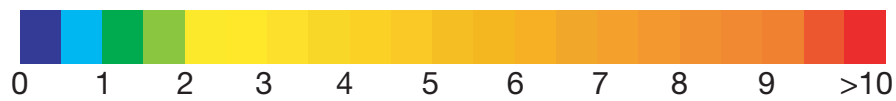

Fig. 2. Biomass in January 2002. (A) Krill Euphausia superba, circles scaled from 0.14 to $38.3 \mathrm{~g} \mathrm{C} \mathrm{m}^{-2}$ (0 to $250 \mathrm{~m}$ ). (B) Calanoides acutus Stages CIV and CV, circles scaled from 0.02 to $1.26 \mathrm{~g} \mathrm{C} \mathrm{m}^{-2}$ (0 to $200 \mathrm{~m}$ ). (C) Species dominating biomass and production in relation to chlorophyll a concentration. Krill dominance, based on upper quartile growth rates, denoted by $\boldsymbol{\Delta}$ and $C$. acutus by $O$. Chlorophyll a represented by a SeaWiFS image, monthly composite for January 2002 


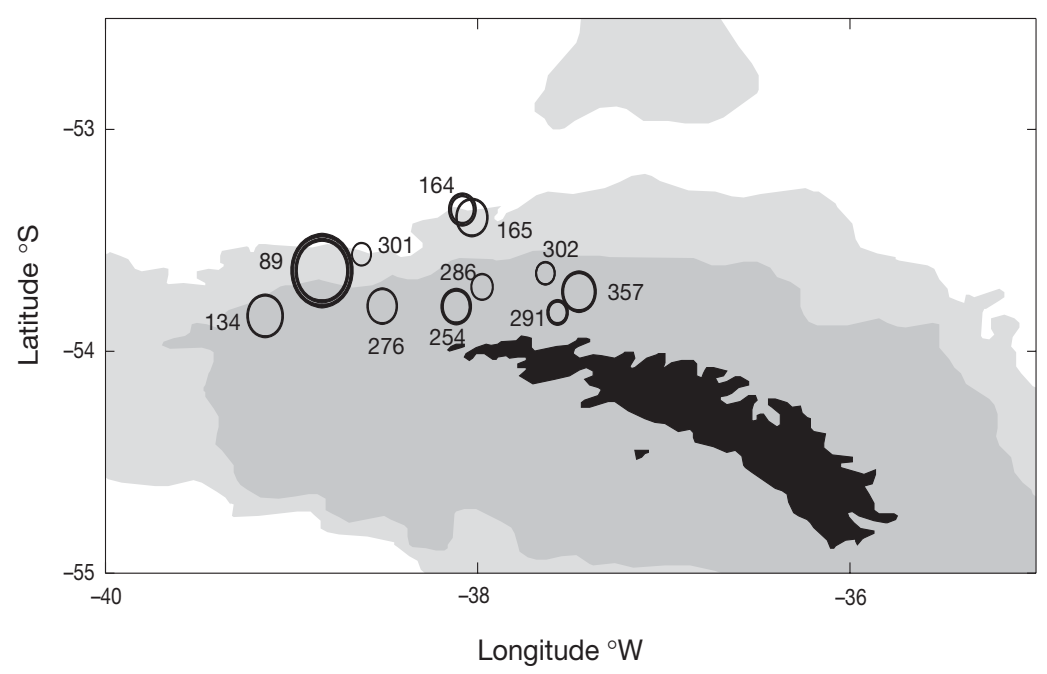

Fig. 3. Euphausia superba. Open circles show the location of swarms sampled during 2002. Size of the circle represents the instantaneous growth rate measurement at that station, circles scaled from 1.16 to $10.59 \%$ body length increase per intermolt period; 2 circles indicate $>1$ net in 1 location. Numbers identify the swarms and correspond to those event numbers used in Table 1 robustness of our results, the role of copepods and the implications of our results over wider scales.

\section{Methodology}

The IGR method is considered the most natural and direct way to measure krill growth in the field (Nicol et al. 2000, Ross et al. 2000). Other methods rely on being able to sample the same field population repeatedly and without bias, for example, for mortality, advection and sampling selectively (Mackintosh 1972, Clarke \& Morris 1983, Rosenberg et al. 1986, Reid 2001). However, the IGR method does have limitations. In this study we found that GIs declined with the length of time that krill were kept in the experiments
Table 4. Daily estimated production $\left(\mathrm{g} \mathrm{C} \mathrm{m}^{-2} \mathrm{~d}^{-1}\right)$ for krill Euphausia superba and Calanoides acutus Stages CIV and CV combined; coefficients of variation (\%) are in parentheses. Higher value in each year in bold

\begin{tabular}{|lcc|}
\hline Year & Krill & C. acutus \\
\hline $1995 / 1996$ & $\mathbf{0 . 0 2 2}(\mathbf{4 8 )}$ & $0.005(45)$ \\
$1996 / 1997$ & $0.021(35)$ & $\mathbf{0 . 0 2 7}(\mathbf{4 5})$ \\
$1997 / 1998$ & $0.017(39)$ & $\mathbf{0 . 0 6 9}(\mathbf{1 8 )}$ \\
$1998 / 1999$ & $0.010(31)$ & $\mathbf{0 . 0 1 6}(\mathbf{2 1 )}$ \\
$2001 / 2002$ & $\mathbf{0 . 0 3 9 ( 6 0 )}$ & $0.021(31)$ \\
Mean & 0.022 & $\mathbf{0 . 0 2 6}$ \\
\hline
\end{tabular}

Krill production exceeded that of C. acutus in 11 out of 25 comparisons. C. acutus biomass dominated areas with higher standing stocks of chlorophyll, whilst higher krill biomass was generally associated with lower standing stocks of chlorophyll, as represented by SeaWiFS images (Fig. 2C).

\section{DISCUSSION}

This is one of the only studies that directly measures the relative production of krill and copepods in a defined area and compares them in the same units. While krill Euphausia superba biomass was approximately 5 times that of Stage CIV and CV Calanoides acutus in the South Georgia region, its production was about equal. This result applies to an area noted for its krill stocks, krill-dependent predators and classical 'krill-dominated' food web. We discuss below the
Table 5. Production ( $\mathrm{g} \mathrm{C} \mathrm{m}^{-2} \mathrm{~d}^{-1}$ ) of krill Euphausia superba and Calanoides acutus Stages CIV and CV during 2002. A single value of $g$ (mass-specific instantaneous growth rate) for each stage was used for $C$. acutus derived from the model of Tarling et al. (2004), whilst the value for krill was the average of 17 experiments carried out in the vicinity of the boundary box. Station numbers refer to those indicated for the boundary box in Fig. 1. Krill biomass was integrated over approximately $9 \mathrm{~km}$ either side of the station. Bold print indicates which of the 2 values was highest

\begin{tabular}{|rcc|}
\hline Stn & Krill & C. acutus \\
\hline 1 & $\mathbf{0 . 0 4 8 8}$ & 0.0120 \\
2 & 0.0016 & $\mathbf{0 . 0 4 7 8}$ \\
3 & 0.0018 & $\mathbf{0 . 0 6 8 6}$ \\
4 & $\mathbf{0 . 0 4 1 1}$ & 0.0263 \\
5 & 0.0545 & $\mathbf{0 . 1 2 4 8}$ \\
6 & 0.0012 & $\mathbf{0 . 0 4 7 7}$ \\
7 & 0.0032 & $\mathbf{0 . 0 5 7 1}$ \\
8 & 0.0430 & $\mathbf{0 . 0 5 3 7}$ \\
9 & 0.0061 & $\mathbf{0 . 0 8 2 0}$ \\
10 & $\mathbf{0 . 0 9 2 8}$ & 0.0260 \\
11 & 0.0065 & $\mathbf{0 . 0 4 0 7}$ \\
12 & 0.0519 & $\mathbf{0 . 0 7 2 3}$ \\
13 & $\mathbf{0 . 0 2 2 7}$ & 0.0032 \\
14 & 0.0045 & $\mathbf{0 . 1 0 7 1}$ \\
15 & $\mathbf{0 . 0 1 0 0}$ & 0.0062 \\
16 & $\mathbf{0 . 0 6 3 1}$ & 0.0025 \\
17 & $\mathbf{0 . 0 2 7 1}$ & 0.0131 \\
18 & $\mathbf{0 . 0 2 9 4}$ & 0.0068 \\
19 & $\mathbf{0 . 3 2 1 6}$ & 0.0097 \\
20 & $\mathbf{0 . 0 5 3 4}$ & 0.0031 \\
21 & $\mathbf{0 . 0 2 7 6}$ & 0.0088 \\
22 & 0.0297 & $\mathbf{0 . 1 0 2 0}$ \\
23 & 0.0094 & $\mathbf{0 . 0 4 8 6}$ \\
24 & 0.0043 & $\mathbf{0 . 0 0 8 2}$ \\
25 & 0.0352 & $\mathbf{0 . 0 4 6 0}$ \\
\hline & & \\
\hline
\end{tabular}


(G. A. Tarling et al. unpubl. data). This may be because the individuals were maintained in filtered seawater as a means of controlling conditions between experiments. Nevertheless, this effect is relatively small in the current context, since we estimated it would lower production by only $6 \%$.

Comparisons of krill and copepod production will also be sensitive to the exact environmental conditions of each measurement. This does not present a problem for biomass values that were calculated for krill and copepods from the same studies. However, growth rates were obtained from differing numbers of studies for each of the 2 taxa. Those of Calanoides acutus were derived from multi-year stage-frequency data from the Scotia Sea and multi-year carbon-mass and stageduration data from South Georgia (Shreeve et al. 2002, Tarling et al. 2004). Krill growth, on the other hand, was measured from 1 study. Nevertheless, chl a concentrations were typical in this summer (P. Ward et al. unpubl. data), and the $0.10 \mathrm{~mm} \mathrm{~d}^{-1}$ growth rate is at the upper end of the literature values (e.g. Morris \& Keck 1984, Bucholz 1985, Quetin \& Ross 1991, Ross et al. 2000). Indeed they are similar to values obtained there the following year (A. Atkinson et al. unpubl. data). We do not believe that our estimated growth and production rates for krill are unrealistically lower than those for C. acutus.

\section{Implications over wider scales}

South Georgia is atypical of the Southern Ocean, having exceptionally high stocks of phytoplankton, mesozooplankton and krill (Ward et al. 1995, Whitehouse et al. 1996, Brierley et al. 1997, Atkinson et al. 2004.) The key question is: How do our calculated ratios of krill to Calanoides acutus production in this small area relate to the broader picture? In other words, does total copepod production exceed that of krill throughout the Southern Ocean?

At South Georgia in summer, Stages CIV and CV of Calanoides acutus comprised about $25 \%$ of the copepod biomass, yet production of just these 2 stages was slightly higher than that of krill. Including the production of other copepods, total production may exceed that of krill at South Georgia.

To be able to extrapolate the results to wider scales, we determined whether krill or copepods showed different degrees of concentration at South Georgia compared to the rest of their distributional range. Calanoides acutus are more evenly spread throughout the Southern Ocean than krill, which are highly concentrated within parts of the SW Atlantic sector (Baker 1959, Marr 1962, Andrews 1966, Atkinson 2004). Taking copepods as a single group, summer mesozoo- plankton biomass is dominated in the Southern Ocean by copepods (Hopkins 1971, Voronina 1998), and values at South Georgia are high: 12 to $13 \mathrm{mg} \mathrm{DM} \mathrm{m}^{-2}$ (Ward et al. 1995, Atkinson et al. 1996), around 4 to 6 times the amounts recorded in large-scale surveys across the Southern Ocean (e.g. Foxton 1956, Hopkins 1971, Voronina 1998, Atkinson et al. 2001).

Given the patchiness of krill, their exact degree of concentration at South Georgia is hard to measure. A conservative estimate is possible using the grid cells in Fig. 1b of Atkinson et al. (2004). Based on the 2 cells that include South Georgia (i.e. a broad area of ocean $5^{\circ}$ of longitude by $4^{\circ}$ of latitude, with South Georgia in the center), mean krill density there is 55 ind. $\mathrm{m}^{-2}$, 5.6 times that of the overall sampled Southern Ocean. A corresponding estimate for biomass, derived from the data of Voronina (1998), suggests an even stronger concentration of krill near South Georgia.

We can conclude therefore that the biomass values of copepods and krill are inflated by similar amounts at South Georgia. Therefore, the results we encountered here are of a wider relevance on a circumpolar scale. Nevertheless, we must consider that our mid-summer, high-chlorophyll comparison does not extrapolate easily to low-chlorophyll conditions or to periods other than the summer growth season. Krill do not enter diapause as do individuals of Calanoides acutus, and they have been observed feeding throughout the winter, although it is still being debated whether they are able to grow at summer rates or only meet basal metabolic costs (Huntley et al. 1994, Quetin et al. 1994). Regardless of the exact ratio of copepod to krill production, copepod production is clearly substantial, even in areas renowned for being krill 'hotspots'. This leads to questions concerning the fate of this production within the food web.

\section{Ecological implications}

At South Georgia the highest krill biomass was not generally located in the most productive waters. Monthly composite SeaWiFS images (Fig. 2C) show a persistent phytoplankton bloom in the off-shelf area of the survey box; a feature characteristic of the area (Atkinson et al. 2001, Korb et al. 2004). However, krill biomass was generally associated with the lower chlorophyll shelf waters, again a pattern frequently observed in this region (Trathan et al. 2003), whilst high mesozooplankton biomass was found in the offshelf area and along the shelf break in regions characterized by a particularly high abundance of chlorophyll (P. Ward et al. unpubl. data). This partitioning is likely to be caused by bottom-up control. Highest nutrient depletion was seen off the shelf, in areas of the highest 
chl $a$, whilst little depletion was seen in on-shelf areas, where chl a biomass was low and krill biomass high, suggesting that little phytoplankton growth had occurred there (M. J. Whitehouse et al. unpubl. data). Egg production was highest for copepods in the offshelf area, falling to approximately half these rates at the on-shelf locations (P. Ward et al. unpubl. data). This suggests that the lower copepod abundance here is due to the lower levels of reproduction rather than topdown control.

Krill have repeatedly been found at South Georgia in greater concentrations in colder waters over the shelf (Trathan et al. 2003). This tendency, albeit with lower chlorophyll concentrations (Shreeve et al. 2002), may be explained by the recent findings of A. Atkinson et al. (unpubl. data), which suggest that krill are thermally stressed above $1^{\circ} \mathrm{C}$, rendering the areas of highest production around South Georgia unavailable to them.

The relative contribution of copepods and krill to secondary production in such chlorophyll-rich environments has implications for energy flux. Krill and copepods have quite different life-history strategies and so the fate of secondary production arising from each group may be quite different. Krill remain in the upper water column throughout the year, whilst many biomass-dominant copepods migrate to depth to overwinter.

Krill food chains are well documented (Hopkins \& Torres 1989, Everson \& Goss 1991, Hopkins et al. 1993), and the krill stocks around South Georgia support a high biomass of krill-dependant predators. Krill do not normally reproduce around South Georgia (Marr 1962); somatic growth therefore dominates their production. Trathan et al. (1995) estimated the level of predation on krill by seals and breeding seabirds to be in the order of $6.8 \times 10^{6} \mathrm{t}$ in the area of South Georgia during the attendance time of breeding predators (233 d). This equates to a daily demand of $2.9 \times 10^{4} \mathrm{t}$ $\mathrm{d}^{-1}$, or $2.9 \times 10^{9} \mathrm{~g} \mathrm{C} \mathrm{d}^{-1}$ (applying the same WM to CM ratio used above). We define the foraging area for these predators as the area up to and including the continental shelf around South Georgia, as highest krill densities are found there (Everson \& Goss 1991). This represents an area of around $300 \times 140 \mathrm{~km}$, equivalent to $42000000000 \mathrm{~m}^{2}$, and equates to a demand of $0.07 \mathrm{~g} \mathrm{C} \mathrm{m}^{-2} \mathrm{~d}^{-1}$, considerably more than the estimated daily production of krill in this area $\left(0.022 \mathrm{~g} \mathrm{C} \mathrm{m}^{-2}\right)$. Whilst the precise foraging area is not known for these predator species, a foraging area 3 times the size would be required to balance the estimated production of krill. This suggests that all krill production is rapidly transferred to higher trophic levels within a season.

The fate of Calanoides acutus production is likely to be divided between the transfer to higher trophic lev- els and sequestration at depth. For $2 / 3$ of the year these copepods reside below $500 \mathrm{~m}$ (Tarling et al. 2004), and during this time the estimated mortality rate from starvation is $0.00115 \mathrm{~d}^{-1}$, while that from predation is between 0.00215 and $0.00415 \mathrm{~d}^{-1}$ (Tarling et al. 2004). This equates to a total population loss during overwintering of up to $75 \%$. Mean biomass of Stage CIV and $\mathrm{CV}$ C. acutus is, on average, $0.6 \mathrm{~g} \mathrm{C} \mathrm{m}^{-2}$, measured in the month prior to the onset of diapause (see Table 3 ), suggesting that up to $0.45 \mathrm{~g} \mathrm{C} \mathrm{m}^{-2}$ of this standing stock may be lost during the winter. Total production of C. acutus during its residence time in the upper layers is in the order of $2.6 \mathrm{~g} \mathrm{C} \mathrm{m}^{-2}$ (calculated from a mean daily production of 0.026 [Table 4] $\times 100 \mathrm{~d}$ in the epipelagic). Therefore, around $17 \%$ of production achieved within 1 season may be directly transported to depth and sequestered there.

The fate of the remaining copepod production is more poorly understood in the Southern Ocean. Hopkins et al. (1993) highlighted the importance of copepods in the food web at the marginal ice zone during spring. Here, Calanoides acutus formed a major part of the diet of the mesopelagic fish Electrona antarctica (Hopkins et al. 1993), one of the most numerically and biomass-dominant fish in the Southern Ocean (Greely et al. 1999). This, in turn, was one of the most important prey items in the diet of sea birds (blue, cape, wilsons, white chinned and snow petrel, Antarctic prion, Antarctic tern, emperor and king penguins), and of Antarctic fur seals (see Sabourenkov 1992). Around South Georgia, the mackerel icefish Champsocephalus gunnari becomes an important dietary item for Antarctic fur seals during their breeding season (Reid \& Arnould 1996). In this case, the copepod Drepanopus forcipatus is the single most important species in its larval diet (North \& Ward 1990). C. acutus has also been found to be the major food item in the stomach contents of the larval fish Gobionotothen gibberifrons, found in shelf waters around South Georgia (R. S. Shreeve pers. obs.), whilst some accounts suggest they may be consumed by Sei whales in small quantities when krill are scarce (Matthews 1938, Pervushin 1968). These trophic pathways have received little attention in the South Georgia area, but may account for a considerable amount of carbon flux and yield to higher predators. Understanding this alternative pathway should, therefore, be a priority.

Acknowledgements. We thank the officers and crew onboard RRS 'James Clark Ross' for their help in collection of material and in the successful completion of the cruises and to Doug Bone for his support in sample collection, Kate Arnold for her enthusiasm in helping with the krill IGR experiments and to Pete Rothery for his statistical advice. Comments from Andrew Hirst and 2 anonymous reviewers considerably improved the manuscript. 


\section{LITERATURE CITED}

Andrews KJH (1966) Distribution and life-history of Calanoides acutus (Giesbrecht). Discov Rep 34:117-162

Atkinson A, Shreeve RS, Pakhomov EA, Priddle J, Blight SP, Ward P (1996) Zooplankton response to a phytoplankton bloom near South Georgia, Antarctica. Mar Ecol Prog Ser 144:195-210

Atkinson A, Schnack-Schiel SB, Ward P, Marin V (1997) Regional differences in the life cycle of Calanoides acutus (Copepoda: Calanoida) within the Atlantic sector of the Southern Ocean. Mar Ecol Prog Ser 150:99-111

Atkinson A, Whitehouse MJ, Priddle J, Cripps GC, Ward P, Brandon BA (2001) South Georgia, Antarctica: a productive, cold water, pelagic ecosystem. Mar Ecol Prog Ser 216: 279-308

Atkinson A, Siegel V, Pakhomov E, Rothery P (2004) Long term decline in krill stock and increase in salps within the Southern Ocean. Nature 432:100-103

Baker A de C (1959) The distribution and life history of Euphausia triacantha Holt and Tattersall. Discov Rep 29: 309-340

Brierley AS, Watkins JL (1996) Acoustic targets at South Georgia and the South Orkney Islands during a season of krill scarcity. Mar Ecol Prog Ser 138:51-61

Brierley AS, Watkins JL, Murray AWA (1997) Interannual variability in krill abundance at South Georgia. Mar Ecol Prog Ser 150:87-98

Buchholz F (1985) Moult and growth in euphausiids. In: Siegfried WR, Condy PR, Laws RM (eds) Antarctic nutrient cycles and food webs. Springer-Verlag, Berlin, p 339-345

Clarke A (1985) Food webs and interactions: an overview of the Antarctic ecosystem. In: Bonner WN, Walton DWH (eds) Antarctica. Pergamon Press, Oxford, p 329-350

Clarke A, Morris DJ (1983) Towards an energy budget for krill: physiology and biochemistry of Euphausia superba Dana. Polar Biol 2:69-86

Conover RJ, Huntley M (1991) Copepods in ice-covered seas - distribution, adaptations to seasonally limited food, metabolism, growth patterns and life cycle strategies in polar seas. J Mar Syst 2:1-41

Everson I (1977) The living resources of the Southern Ocean. In: Southern Ocean fisheries survey programme. FAO, Rome

Everson I, Goss C (1991) Krill fishing activities in the southwest Atlantic. Antarct Sci 4:351-358

Foxton P (1956) The distribution of the standing stock of zooplankton in the Southern Ocean. Discov Rep 28:191-236

Godlewska M (1996) Vertical migrations of krill (Euphausia superba Dana). Pol Arch Hydrobiol 43:9-63

Greely TM, Gartner JV Jr, Torres JJ (1999) Age and growth of Electrona antarctica (Pisces: Myctophidae), the dominant mesopelagic fish in the Southern Ocean. Mar Biol 133: 145-158

Hamner WM, Hamner PP (2000) Behaviour of Antarctic krill (Euphausia superba): schooling, foraging, and antipredatory behaviour. Can J Fish Aquat Sci 57(3):192-202

Harris RP, Wiebe PH, Lenz J, Skjoldal HR, Huntley M (2000) (eds) Zooplankton methodology manual. Academic Press, London

Hempel G (1985) Antarctic marine food webs. In: Siegfried WR, Condy PR, Laws RM (eds) Fourth SCAR symposium on Antarctic biology. Springer-Verlag, Berlin, p 266-270

Hopkins TL (1971) Zooplankton standing crop in the Pacific sector of the Antarctic. In: Llano GW, Wallen IE (eds) Biology of the Antarctic seas. IV. Antarct Res Ser 17:347-362
Hopkins TL, Torres JJ (1989) Midwater food web in the vicinity of a marginal ice zone in the western Weddell Sea. Deep-Sea Res 36:543-560

Hopkins TL, Ainley DG, Torres JJ, Lancraft TM (1993) Trophic structure in open waters of the marginal ice zone in the Scotia-Weddell confluence region during spring (1983). Polar Biol 13:389-397

Huntley ME, Nordhausen W, Lopez MDG (1994) Elemental composition, metabolic activity and growth of Antarctic krill Euphausia superba during winter. Mar Ecol Prog Ser 107:23-40

Ikeda T, Kirkwood R (1989) Metabolism and body composition of two euphausiids (Euphausia superba and E. crystallorophias) collected under pack-ice of Enderby Land, Antarctica. Mar Biol 100:301-308

Jolly GM, Hampton I (1990) A stratified random transect design for acoustic surveys of fish stocks. Can J Fish Aquat Sci 47:1282-1291

Korb RE, Whitehouse MJ, Ward P (2004) SeaWiFS in the Southern Ocean: spatial and temporal variability in phytoplankton biomass around South Georgia. Deep-Sea Res II 51:99-116

Mackintosh NA (1934) Distribution of the macroplankton in the Atlantic sector of the Antarctic. Discov Rep 9:65-160

Mackintosh NA (1972) Life cycle of Antarctic krill in relation to ice and water conditions. Discov Rep 36:1-94

MacLennan DN, Simmonds EJ (1992) Fisheries acoustics. Chapman \& Hall, London

Madureira LSP, Everson I, Murphy EJ (1993) Interpretation of acoustic data at two frequencies to discriminate between Antarctic krill (Euphausia superba) and other scatterers. J Plankton Res 15:787-802

Marr JWS (1962) The natural history of the Antarctic krill (Euphausia superba Dana). Discov Rep 32:33-464

Matthews LH (1938) The Sei whale, Balaenoptera borealis. Discov Rep 17:185-281

Mauchline J (1998) The biology of calanoid copepods. Adv Mar Biol 33:1-710

Miller DGM, Hampton I (1989) Biology and ecology of the Antarctic krill (Euphausia superba Dana). Biomass Sci Ser 9:1-166

Morris DJ, Keck A (1984) The time course of the moult cycle and growth of Euphausia superba in the laboratory. Kiel Meeresforsch 30(2):94-100

Morris DJ, Watkins JL, Ricketts C, Buchholz F, Priddle J (1988) An assessment of the merits of length and weight measurements of Antarctic krill Euphausia superba. Br Antarct Surv Bull 79:27-50

Murphy EJ, Morris DJ, Watkins JL, Priddle J (1988) Scales of interaction between Antarctic krill and the environment. In: Sahrhage D (ed) Antarctic Ocean and resources variability. Springer-Verlag, Berlin, p 120-130

Nicol S, Stolp M, Cochran T, Geijsel P, Marshall J (1992) Growth and shrinkage of Antarctic krill Euphausia super$b a$ from the Indian sector of the Southern Ocean during summer. Mar Ecol Prog Ser 89:175-181

Nicol S, Kitchener J, King R, Hosie G, de la Mare W (2000) Population structure and condition of Antarctic krill (Euphausia superba) off East Antarctica $\left(80-150^{\circ} \mathrm{W}\right)$ during the austral summer of 1995/1996. Deep-Sea Res II 47(12/13):2489-2517

North AW, Ward P (1990) The feeding ecology of larval fish in an Antarctic fjord, with emphasis on Champsocephalus gunnari. In: Kerry K, Hemple G (eds) Antarctic ecosystems: ecological change and conservation. Proc 5th SCAR Symp Antarctic Biology. Springer-Verlag, Berlin, p 299-307 
Pervushin AS (1968) Observations of the behaviour and feeding of whalebone whales in the area of the Crozet Islands. Oceanology 8:110-115

Quetin LB, Ross RM (1991) Behavioural and physiological characteristics of the Antarctic krill, Euphausia superba. Am Zool 31:49-63

Quetin LB, Ross RM, Clarke A (1994) Krill energetics: seasonal and environmental aspects of the physiology of Euphausia superba. In: El-Sayed (ed) Southern Ocean ecology: the BIOMASS perspective. Cambridge University Press, Cambridge, p 165-184

Reid K (2001) Growth of Antarctic krill Euphausia superba at South Georgia. Mar Biol 138:57-62

Reid K, Arnould JPY (1996) The diet of Antarctic fur seals Arctocephalus gazella during the breeding season at South Georgia. Polar Biol 16:105-114

Rosenberg AA, Beddington JR, Basson M (1986) Growth and longevity of krill during the first decade of pelagic whaling. Nature 324:152-153

Ross RM, Quetin LB, Baker KS, Vernet M, Smith RC (2000) Growth limitation in young Euphausia superba under field conditions. Limnol Oceanogr 45(1):31-43

Sabourenkov E (1992) Myctophids in the diet of Antarctic predators. Selected Scientific Papers 1991. Scientific Committee for the Conservation of Antarctic Marine Living Resources. CCAMLR, Hobart, p 335-368

Schnack SB (1985) Feeding by Euphausia superba and copepod species in response to varying concentrations of phytoplankton. In: Siegfried WR, Condy PR, Laws RM, (eds) Antarctic nutrient cycles and food webs. SpringerVerlag, Berlin, p 311-323

Shreeve RS, Ward P, Whitehouse MJ (2002) Copepod growth and development around South Georgia: relationships

Editorial responsibility: Otto Kinne (Editor-in-Chief), Oldendorf/Luhe, Germany with temperature, food and krill. Mar Ecol Prog Ser 233: 169-183

Tarling G, Shreeve RS, Ward P, Atkinson A, Hirst A (2004) Life-cycle phenotypic composition and mortality of Calanoides acutus (Copepoda: Calanoida) in the Scotia Sea: a modelling approach. Mar Ecol Prog Ser 272:165-181

Tranter DJ (1982) Interlinking of physical and biological processes in the Antarctic Ocean. Oceaonogr Mar Biol Annu Rev 20:11-35

Trathan PN, Everson I, Miller DGM, Watkins JL, Murphy EJ (1995) Krill biomass in the Atlantic. Nature 373:201-202

Trathan PN, Brierley AS, Brandon MA, Bone DG, Goss C, Grant SA, Murphy EJ, Watkins JL (2003) Oceanographic variability and changes in Antarctic krill (Euphausia superba) abundance at South Georgia. Fish Oceanogr 12(6):1-15

Voronina NM (1998) Comparative abundance and distribution of major filter-feeders in the Antarctic pelagic zone. J Mar Syst 17:375-390

Ward P, Atkinson A, Murray AWM, Wood AG, Williams R, Poulet SA (1995) The summer zooplankton community at South Georgia: biomass, vertical migration and grazing. Polar Biol 15:195-208

Watkins JL (2000) Sampling krill: direct sampling. In: Everson I (ed) Krill: biology, ecology and fisheries. Blackwell Scientific, Oxford, p 8-19

Watkins JL, Brierley AS (2002) Verification of acoustic techniques used to identify Antarctic krill. ICES J Mar Sci 59: $1326-1336$

Whitehouse MJ, Priddle J, Symon C (1996) Seasonal and annual change in seawater temperature, salinity, nutrient and chlorophyll a distributions around South Georgia, South Atlantic. Deep-Sea Res I 43:425-443

Submitted: August 20, 2004; Accepted: March 31, 2005 Proofs received from author(s): May 26, 2005 